\title{
Pengaruh Pemberian Pakan Protein Mikropartikel dan Probiotik terhadap Kecernaan Lemak dan Perlemakan Daging pada Ayam Broiler
}

\author{
Effect of Feeding Microparticles Protein Diet and Probiotics on Fat Digestibility and Meat \\ Fat Deposition in Broiler Chicken
}

\author{
E. Harumdewi ${ }^{1}$, N. Suthama ${ }^{2}$, I. Mangisah ${ }^{2}$ \\ ${ }^{1}$ Mahasiswa Program Sarjana Fakultas Peternakan dan Pertanian, Universitas Diponegoro \\ ${ }^{2}$ Dosen Fakultas Peternakan dan Pertanian, Universitas Diponegoro \\ Kampus drh. R. Soedjono Koesoemowardjojo Tembalang, Semarang 50275 \\ Email: ebaharumdewii@gmail.com
}

\begin{abstract}
This study aimed to evaluate the effect of feeding microparticles diet with inclusion of probiotics on fat digestibility and meat fat deposition in broiler chicken. Experimental animals were 100 birds of one day old broiler (males and females were 50 birds, respectively) with average body weight of $46 \pm 2.77 \mathrm{~g}$. Treatments applied were T0 (21\% intact protein as standard feed), T1 (18\% intact protein feed), T2 (18\% microparticle protein feed), T3 (T1 + $1.2 \mathrm{ml}$ Lactobacillus sp.), $\mathrm{T} 4(\mathrm{~T} 2+1.2 \mathrm{ml}$ Lactobacillus sp.). One ml culturing solution of Lactobacillus sp. was equal to $10^{8} \mathrm{cfu}$. Parameters observed were fat digestibility, fat mass of meat, abdominal fat and daily weight gain. The study was assigned in a completely randomized design with 5 treatments and 4 replications (5 birds each). Data were analyzed by using analysis of variance and continued to Duncan test at 5\% probability. Dietary treatments were given from day 21 until day 42 . The results showed that T4 had the highest fat digestibility value and significantly different $(\mathrm{P}<0,05)$ compared to $\mathrm{T} 0, \mathrm{~T} 1$ and $\mathrm{T} 2$, but it was similar to $\mathrm{T} 3$. However, fat mass of meat of $\mathrm{T} 4$ was significantly $(\mathrm{P}<0.05)$ lowest as compared to those of other treatments, and followed by the value of T3 which was siginificantly lower than T0. The lowest abdominal fat and the highest daily body weight gain were found in $\mathrm{T} 4$ and significantly different $(\mathrm{P}<0.05)$ from those in other treatments, but among other treatments were the same. Based on the results, it can be concluded that feeding microparticles protein diet with inclusion of $1,2 \mathrm{ml}$ Lactobacillus $s p$. increase fat digestibility and daily body weight gain with the decrease in fat mass of meat and abdominal fat.
\end{abstract}

Key words : microparticle protein, probiotic, fat digestibilty, meat fat mass, broiler

\begin{abstract}
ABSTRAK
Penelitian bertujuan untuk mengkaji pengaruh pemberian kombinasi protein pakan mikropartikel dan probiotik terhadap kecernaan lemak dan perlemakan daging ayam broiler. Ternak yang digunakan adalah ayam broiler umur sehari (DOC) sebanyak 100 ekor (jantan dan betina maisng-masing 50 ekor), dengan bobot badan rata rata $46 \pm 2,77$ g. Perlakuan yang diterapkan sebagai berikut: T0 (pakan standar dengan protein 21\%), T1 (pakan protein non mikropartikel 18\%), T2 (pakan protein mikropartikel 18\%), T3 (pakan T1 + Lactobacillus sp. 1,2 ml), T4 (pakan T2 + Lactobacillus sp. 1,2 ml). Satu ml hasil kultur Lactobacillus sp. sama dengan $10^{8} \mathrm{cfu}$. Parameter yang diamati adalah kecernaan lemak, massa lemak daging, lemak abdominal dan pertambahan bobot badan harian (PBBH). Penelitian menggunakan rancangan acak lengkap dengan 5 perlakuan dan 4 ulangan (masing - masing 5 ekor). Data dianalisis ragam dan dilajutkan dengan uji Duncan pada probabilitas 5\%. Perlakuan diberikan mulai umur 21 hari sampai 42 hari. Hasil penelitian menunjukkan bahwaT4 memiliki nilai kecernaan lemak tertinggi dan berbeda nyata $(\mathrm{P}<0,05)$ dengan $\mathrm{T} 0, \mathrm{~T} 1$ dan $\mathrm{T} 2$, tetapi sama dengan $\mathrm{T} 3$. Namun, massa lemak daging pada $\mathrm{T} 4$ nyata $(\mathrm{P}<0,05)$ paling rendah dibandingkan perlakuan lain, diikuti oleh nilai pada T3 yang nyata $(\mathrm{P}<0,05)$ lebih rendah dibandingkan $\mathrm{T} 0$, namun antar $\mathrm{T} 0$, T1 dan $\mathrm{T} 2$ sama. Lemak abdominal terendah dan PBBH tertinggi pada perlakuan $\mathrm{T} 4$ dan berbeda nyata $(\mathrm{P}<0,05)$ dengan semua perlakuan lainnya, namun antar perlakuan lainnya sama. Berdasarkan hasil penelitian dapat disimpulkan bahwa pemberian pakan protein mikropartikel dan Lactobacillus sp. 1,2 ml dapat meningkatkan kecernaan lemak dan pertambahan bobot badan harian dengan penurunan massa lemak daging dan lemak abdominal.
\end{abstract}

Kata kunci : protein mikropartikel, probiotik, kecernaan lemak, massa lemak daging, broiler 


\section{PENDAHULUAN}

Penggunaan bahan pakan sumber protein tinggi menyebabkan harga pakan semakin mahal. Kondisi tersebut memerlukan upaya untuk meningkatkan efisiensi penggunaan bahan pakan sumber protein. Satu cara yaitu dengan pengolahan protein menjadi mikropartikel. Protein pakan mikropartikel merupakan hasil pengolahan bahan pakan sumber protein agar memiliki ukuran partikel dalam kisaran mikrometer. Pengecilan ukuran partikel bahan pakan baik pada tepung ikan maupun bungkil kedelai menggunakan perlakuan gelombang ultrasonic dapat meningkatkan pemanfaatan protein dan kalsium (Suthama dan Wibawa, 2016).

Penggunaan protein mikropartikel untuk meningkatkan efisiensi pakan dapat didukung dengan pemberian aditif alami berupa probiotik. Kombinasi tersebut dapat menghasilkan daging ayam broiler yang sehat dengan kriteria rendah lemak namun tinggi protein. Sebagaimana diketahui bahwa probiotik memodifikasi kondisi saluran pencernaan menjadi lebih sehat karena dapat menekan pertumbuhan bakteri patogen. Probiotik menjaga keseimbangan mikroorganisme dalam sistem pencernaan, sehingga memperbaiki pencernaan, daya cerna, meningkatkan penyerapan nutrien serta menjaga kesehatan ternak (Agustina et al., 2007).

Pemberian probiotik dalam penelitian ini menggunakan Lactobacillus sp., diharapkan dapat meningkatkan bakteri menguntungkan sehingga menghasilkan lebih banyak enzim bile salt hydrolase (BSH) untuk menekan mobilisasi lemak. Sehingga pertambahan bobot badan yang dihasilkan diharapkan dapat disertai dengan peningkatan kualitas karkas dan daging yang rendah lemak namun tinggi protein. Pemberian probiotik pada ayam pedaging mampu meningkatkan aktivitas enzim yang dimiliki bakteri probiotik seperti BSH (Daud, 2006). Bile salt hydrolase (BSH) dapat mendekonjugasi garam empedu yang menyebabkan lemak tidak dapat diemulsikan dan diserap sehingga keluar melalui ekskreta (Yunenshi, 2011). Berdasarkan uraian dan latar belakang di atas, pakan protein mikropartikel dan Lactobacillus sp. dapat saling mendukung untuk meningkatkan daya cerna nutrien, terutama protein disatu sisi, namun disisi lain, menurunkan kecernaan lemak dan profil lemak tubuh.

\section{MATERI DAN METODE}

\section{Ternak dan pakan percobaan}

Penelitian menggunakan day old chicken (DOC) ayam broiler sebanyak 100 ekor dengan perbandingan jantan dan betina 1:1 yang memiliki bobot badan rata - rata 46 $\pm 2,77 \mathrm{~g}$. Ayam dipelihara selama 35 hari dan perlakuan dimulai pada umur 8 hari. Masa pemeliharaan awal sampai umur 1 minggu broiler diberi pakan komersial. Probiotik yang digunakan adalah Lactobacillus $s p$. sebanyak $1,2 \mathrm{ml}\left(10^{8} \mathrm{cfu} / \mathrm{ml}\right)$. Formulasi pakan terdiri atas jagung giling, bekatul, bungkil kedelai, tepung ikan, $\mathrm{CaCO}_{3}$ dan premiks (Tabel 1).

\section{Perlakuan, rancangan percobaan dan analisis statistik}

Penelitian menggunakan rancangan acak lengap (RAL) dengan 5 perlakuan dan 4 ulangan, masing - masing 5 ekor ayam.

Perlakuan yang diterapkan sebagai berikut:

$\mathrm{T}_{0}=$ pakan standar protein $21 \%$

$\mathrm{T}_{1}=$ pakan protein non mikropartikel $(18 \%)$

$\mathrm{T}_{2}=$ pakan protein mikropartikel $(18 \%)$

$\mathrm{T}_{3}=$ pakan $\mathrm{T}_{1}+$ Lactobacillus sp. $1,2 \mathrm{ml}\left(10^{8}\right.$ $\mathrm{cfu} / \mathrm{ml})$.

$\mathrm{T}_{4}=$ pakan $\mathrm{T}_{2}+$ Lactobacillus sp. 1,2 $\mathrm{ml}\left(10^{8}\right.$ cfu/ml)

Proses pembuatan protein mikropartikel diawali dengan menghaluskan bahan pakan sumber protein yaitu tepung ikan dan bungkil kedelai. Bahan pakan dihaluskan dan dicampur dengan aquades dengan perbandingan 1:4 (100 g pakan dilarutkan dengan $400 \mathrm{ml}$ aquades) dan dipapar gelombang ultrasonik menggunakan ultrasound transducer selama 60 menit. Bahan pakan kemudian dikeringkan dengan 
Tabel 1. Komposisi dan kandungan nutrien pakan menggunakan protein non - mikro dan mikropartikel

\begin{tabular}{|c|c|c|c|}
\hline \multirow[b]{2}{*}{ Bahan Pakan } & \multicolumn{3}{|c|}{ Komposisi (\%) } \\
\hline & $\begin{array}{c}\text { Non Mikro } \\
\text { Protein } 21 \% \\
\text { (T0) }\end{array}$ & $\begin{array}{l}\text { Non Mikro } \\
\text { Protein } 18 \% \\
\text { (T1 dan T3) }\end{array}$ & $\begin{array}{l}\text { Mikropartikel } \\
\text { Protein } 18 \% \\
(\mathrm{~T} 2 \text { dan } \mathrm{T} 4) \\
\end{array}$ \\
\hline Jagung giling & 48,0 & 50,5 & 50,2 \\
\hline Bekatul & 14,0 & 20,0 & 18,8 \\
\hline Bungkil kedelai & 27,0 & 21,0 & - \\
\hline $\begin{array}{l}\text { Bungkil kedelai mikropartikel } \\
\text { (BKM) }\end{array}$ & - & - & 21,5 \\
\hline Tepung ikan & 10,0 & 7,5 & - \\
\hline Tepung ikan mikropartikel (TIM) & - & - & 8,5 \\
\hline $\mathrm{CaCO} 3$ & 0,5 & 0,5 & 0,5 \\
\hline Premiks & 0,5 & 0,5 & 0,5 \\
\hline Total & 100 & 100 & 100 \\
\hline \multicolumn{4}{|l|}{ Kandungan nutrien $(\%)^{1}$} \\
\hline Energi metabolis $(\mathrm{kkal} / \mathrm{kg})^{2}$ & 2978,41 & 2948,32 & 2947,58 \\
\hline Protein kasar & 21,29 & 18,12 & 18,06 \\
\hline Lemak kasar & 2,81 & 2,57 & 2,70 \\
\hline Serat kasar & 4,27 & 4,77 & 4,71 \\
\hline Kalsium & 0,52 & 0,50 & 0,50 \\
\hline Fosfor & 0,37 & 0,40 & 0,39 \\
\hline Metionin $^{3}$ & 0,45 & 0,39 & 0,41 \\
\hline $\operatorname{Lisin}^{3}$ & 1,37 & 1,12 & 1,17 \\
\hline Arginin $^{3}$ & 1,51 & 1,28 & 1,33 \\
\hline
\end{tabular}

Keterangan: ${ }^{1}$ Berdasarkan Hasil Analisis Bahan Pakan di Laboratorium Ilmu Nutrisi dan Pakan, Fakultas Peternakan dan Pertanian Universitas Diponegoro, (2017); ${ }^{2}$ Berdasarkan Perhitungan menggunakan rumus Balton; ${ }^{3}$ Berdasarkan National Research Council (1994).

bantuan sinar matahari, selanjutnya dibuat pelet. Parameter yang diamati adalah kecernaan lemak kasar, massa lemak daging, lemak abdominal dan pertambahan bobot badan harian $(\mathrm{PBBH})$. Kecernaan lemak kasar diukur dengan metode total koleksi dikombinasi indikator $\mathrm{Fe}_{2} \mathrm{O}_{3}$. selama 3 hari terakhir. Ekskreta ditampung dengan nampan yang sudah dilapisi plastik di bagian bawah kandang. Ekskreta yang telah terkumpul disemprot dengan HCL $0,1 \mathrm{~N}$ setiap 3 jam untuk mencegah penguapan N. Sampel ekskreta sebelum dan sesudah dikeringkan ditimbang, selanjutnya dihomogenkan dan dianalisis menggunakan metode soxhlet untuk mengetahui kadar lemak kasar ekskreta. Jumlah konsumsi lemak dihitung dengan mengalikan jumlah konsumsi dengan persentase kandungan lemak pakan selama total koleksi. Demikian pula ransum dianalisis dan dihitung dengan metode yang sama.

Massa lemak daging (MLD) diukur dari sampel daging yang diambil pada akhir periode pemeliharaan (umur 35 hari). Sampel daging merupakan campuran daging dada, paha, sayap dan punggung setelah dipisahkan dari tulang dan kulit. Daging dicampur dan digiling halus kemudian diambil sampel untuk dianalisis dengan metode soxhlet untuk mengetahui kadar lemak daging. Lemak abdominal diukur dari penimbangan lemak yang ada di rongga perut. Lemak yang ditimbang adalah lemak yang menempel di organ pencernaan seperti gizzard, usus halus, otot abdomen dan dinding rongga perut. Rumus perhitungan parameter adalah sebagai berikut :

Kecernaan lemak kasar $(\%)=$ LK ransum terkonsums $\mathrm{i}-\mathrm{LK}$ feses LK ransum terkonsums $\mathrm{i}$

(Wahju, 1997)

MLD = kadar LK daging $\mathrm{x}$ bobot daging (Mentari et al, 2015)

Persentase lemak abdominal $(\%)=$ bobot lemak abdominal (g) x 100\% bobot hidup (g)

(Salam et al., 2013) 
Pertambahan bobot badan harian = bobot badan akhir - bobot badan awal lama pemelihara an

Data hasil penelitian diuji secara statistik berdasarkan prosedur analisis ragam (uji F). Apabila terdapat pengaruh perlakuan nyata $(\mathrm{P}<0,05)$ dilanjutkan dengan uji wilayah ganda Duncan pada taraf 5\%.

\section{HASIL DAN PEMBAHASAN}

\section{Kecernaan lemak kasar}

Hasil penelitian menunjukkan bahwa kecernaan lemak perlakuan T4 (pakan protein mikropartikel 18\% + Lactobacillus $s p$. $1,2 \mathrm{ml})$ paling tinggi dan berbeda nyata $(\mathrm{P}<0,05)$ dengan $\mathrm{T} 0$ (pakan protein non mikropartikel $21 \%$ tanpa Lactobacillus sp.), T1 (pakan protein non mikropartikel 18\% tanpa Lactobacillus sp.) dan T2 (pakan protein mikropartikel $18 \%$ tanpa Lactobacillus sp.). Berbeda halnya T3 (pakan protein non mikropartikel $18 \%+$ Lactobacillus sp.) sama dengan T4, demikian pula antar perlakuan T0, T1 dan T2. Kecernaan lemak kasar pada ayam Broiler ditunjukkan pada Tabel 2 berikut.

Perlakuan T3 dan T4 mendapatkan penambahan Lactobacillus sp. dan menunjukkan kecernaan lemak lebih tinggi dibandingkan dengan perlakuan yang lain. Apabila jumlah Lactobacillus sp. semakin tinggi maka enzim bile salt hydrolase (BSH) yang dihasilkan semakin banyak. Menurut Daud (2006), keberadaan probiotik terutama Lactobacillus sp. mampu menghasilkan enzim BSH. Enzim BSH yang diproduksi oleh strain bakteri asam laktat membentuk garam empedu dekonjugasi yang tidak mudah mengemulsikan lemak dibanding garam empedu konjugasi, sehingga lemak yang dapat dicerna berkurang.

Namun, penelitian ini tidak sesuai dengan teori bahwa Lactobacillus sp. berperan dalam sekresi enzim (BSH) yang dapat menekan kecernaan lemak. Kecernaan lemak yang tinggi pada penelitian ini bukan karena enzim BSH yang tidak bekerja dengan maksimal, namun, terdapat dominasi aktivitas lipase yang berkaitan dengan imbangan asam lemak jenuh dan tidak jenuh. Penelitian ini menggunakan bungkil kedelai yang lebih dominan daripada tepung ikan. Bungkil kedelai mengandung asam lemak tak jenuh lebih banyak daripada asam jenuh, namun, sebaliknya pada tepung ikan asam lemak jenuh lebih dominan. Bungkil kedelai mengandung saturated fatty acid (SFA) 14,46\%, monounsaturated fatty acid (MUFA) 22,09\% dan polyunsaturated fatty acid (PUFA) 56,46\% (Sotak dan Stein, 2014), sedangkan tepung ikan mengandung SFA 33,25\% dan MUFA 20,23\% (Turan et al., 2007). Imbangan kandungan lemak jenuh dan tidak jenuh pada pakan dapat berpengaruh terhadap metabolisme lemak dalam tubuh. Menurut Mohammed dan Horniakova (2012), pemberian pakan dominan lemak tak jenuh dapat meningkatkan metabolisme lemak agar lebih tersedia untuk pasokan energi daripada mengendap dalam bentuk lemak abdominal.

\section{Massa lemak daging}

Perlakuan T4 (pakan protein mikropartikel $18 \%+$ Lactobacillus sp.) menunjukkan massa lemak daging paling rendah dan berbeda nyata $(\mathrm{P}<0,05)$ dengan keempat perlakuan lainnya (Tabel 2). Perlakuan tersebut menggunakan bungkil kedelai yang dibuat dalam bentuk mikropartikel. Kandungan soybean oligosaccharides (SOS) pada bungkil kedelai juga menjadi berbentuk mikropartikel sehingga dapat dimanfaatkan dengan lebih baik oleh Lactobacillus sp. Fermentasi SOS oleh bakteri asam laktat menghasilkan asam lemak rantai pendek atau short chain fatty acid (SCFA). Krismaputri et al., (2016) menyatakan bahwa bungkil kedelai mengandung SOS yang dapat dimanfaatkan sebagai prebiotik, menghasilkan SCFA yang dapat menurunkan $\mathrm{pH}$ usus sehingga persentase bakteri patogen menurun. 
Tabel 2. Rataan kecernaan lemak, massa lemak daging, lemak abdominal dan pertambahan bobot badan harian pada ayam broiler

\begin{tabular}{ccccc}
\hline Perlakuan & $\begin{array}{c}\text { Kecernaan Lemak } \\
\text { Kasar } \\
(\%)\end{array}$ & $\begin{array}{c}\text { Massa Lemak } \\
\text { Daging } \\
(\mathrm{g})\end{array}$ & $\begin{array}{c}\text { Lemak } \\
\text { Abdominal } \\
(\%)\end{array}$ & $\begin{array}{c}\text { PBBH } \\
(\mathrm{g} / \mathrm{hari})\end{array}$ \\
\hline T0 & $73,14^{\mathrm{bc}}$ & $13,03^{\mathrm{a}}$ & $2,27^{\mathrm{a}}$ & $23,71^{\mathrm{b}}$ \\
T1 & $73,42^{\mathrm{bc}}$ & $12,65^{\mathrm{ab}}$ & $2,12^{\mathrm{a}}$ & $22,66^{\mathrm{b}}$ \\
T2 & $72,13^{\mathrm{c}}$ & $12,33^{\mathrm{ab}}$ & $2,10^{\mathrm{a}}$ & $21,55^{\mathrm{b}}$ \\
T3 & $76,03^{\mathrm{ab}}$ & $11,76^{\mathrm{b}}$ & $2,15^{\mathrm{a}}$ & $23,25^{\mathrm{b}}$ \\
T4 & $77,34^{\mathrm{a}}$ & $10,68^{\mathrm{c}}$ & $1,64^{\mathrm{b}}$ & $26,03^{\mathrm{a}}$ \\
\hline
\end{tabular}

Keterangan : Superskrip yang berbeda menunjukkan perbedaan yang nyata $(\mathrm{P}<0,05)$.

Selain itu, low molecular weight carbohydrate (LMWC) yang misalnya berasal dari jagung juga dapat menghasilkan produk metabolis SCFA yang sama. Menurut Kocher et al. (2003) low molecular weight carbohydrate (LMWC) pada jagung bersifat fermentatif dan menghasilkan suasana asam.

Sebagaimana telah dijelaskan sebelumnya, meningkatnya BAL dapat dikaitkan dengan kemampuan produksi enzim bile salt hydrolase (BSH). Menurut Daud (2006), BSH mendekonjugasikan garam empedu sehingga cenderung tidak mudah mengemulsikan lemak. Namun, pada penelitian ini dapat diasumsikan bahwa $\mathrm{BSH}$ tidak efektif karena tergantung pada perbandingan asam lemak tidak jenuh yang lebih banyak daripada asam lemak jenuh yang menyebabkan meningkatnya kecernaan lemak. Kecernaan lemak yang meningkat tidak selalu diiringi dengan meningkatnya deposisi lemak dalam daging karena tergantung pada metabolisme asam lemak jenuh dan tidak jenuh. Menurut Mohammed dan Horniakova (2012) konsumsi asam lemak jenuh dapat meningkatkan kandungan lemak daging, sebaliknya, penggantian asam lemak jenuh dengan asam lemak tak jenuh dapat menurunkan lemak daging. Asam lemak jenuh memiliki sifat lebih mudah dihidrolisis dalam hati sehingga lemak lebih banyak didistribusikan ke dalam jaringan, dalam penelitian ini dinyatakan sebagai massa lemak daging.

\section{Lemak abdominal}

Perlakuan T4 (pakan protein mikropartikel $18 \%+$ Lactobacillus sp.) menghasilkan lemak abdominal paling rendah dan berbeda nyata $(\mathrm{P}<0,05)$ dengan keempat perlakuan lain (Tabel 2). Sebagaimana telah dijelaskan sebelumnya, perlakuan tersebut menggunakan bungkil kedelai mikropartikel yang menyebabkan kandungan SOS juga berbentuk mikropartikel sehingga lebih termanfaatkan oleh Lactobacillus sp. Fermentasi SOS tersebut menghasilkan SCFA yang menyebabkan $\mathrm{pH}$ saluran pencernaan menurun sehingga populasi bakteri patogen menurun dan populasi bakteri menguntungkan meningkat. Peningkatan populasi BAL menyebabkan produksi BSH juga meningkat. Menurut teori yang dikemukakan oleh Kirana et al., (2017), BSH mendekonjugasi garam empedu sehingga lemak kurang dapat diserap oleh usus halus. Sebelumnya juga telah disinggung bahwa pada penelitian ini BSH tidak efektif bekerja karena didominasi oleh aktivitas lipase yang berkaitan dengan perbandingan asam lemak tidak jenuh dan tidak jenuh yang menyebabkan kecernaan lemak meningkat. Meskipun terjadi peningkatan kecernaan lemak akibat imbangan lemak tak jenuh yang lebih tinggi dibandingkan lemak jenuh, fenomena tersebut tidak sejalan dengan deposisi lemak abdominal yang rendah. Menurut Mohammed dan Horniakova (2012), pemberian pakan dominan lemak tak jenuh dapat meningkatkan metabolisme lemak agar lebih tersedia untuk pasokan energi daripada mengendap di dinding perut. Nilai penurunan lemak abdominal seperti dilaporkan oleh Mohammed dan Horniakova (2012) sebesar $1,19 \%$ pada perlakuan penambahan lemak tidak jenuh dibandingkan dengan perlakuan kontrol yaitu $1,98 \%$. 
Pertambahan bobot badan harian (PBBH) Perlakuan T4 (pakan protein mikropartikel + Lactobacillus $s p$.) menghasilkan $\mathrm{PBBH}$ paling tinggi dan berbeda nyata $(\mathrm{P}<0,05)$ dengan perlakuan lain (Tabel 2). Pertambahan bobot badan secara kualitas tidak lepas dari dukungan kemampuan deposisi protein yang diukur sebagai massa protein daging. Sebagaimana telah dibahas sebelumnya bahwa massa lemak daging perlakuan T4 menunjukkan hasil paling rendah dibanding perlakuan lain. Massa lemak daging mempunyai hubungan negatif dengan massa protein daging. Ini berarti penurunan massa lemak diikuti peningkatan massa protein daging, begitu pula sebaliknya. Menurut Hartono et al. (2013), lemak daging berkorelasi negatif terhadap protein daging. Kondisi tersebut ditunjang oleh peningkatan massa protein daging dan penurunan $\mathrm{N}^{\tau}$-Methylhistidine sebagai bukti terjadinya pengurangan perombakan protein tubuh pada broiler (Suthama dan Wibawa, 2017) akibat pemberian pakan protein mikropartikel dan Lactobacillus sp. Disamping itu, pakan mikropartikel dengan penambahan Lactobacillus sp. dibandingkan dengan pakan non mikropartikel dapat meningkatkan retensi kalsium $(0,17 \%$ vs $0,30 \%)$ dan pertumbuhan tulang $(9,11 \mathrm{~cm}$ vs $9,60 \mathrm{~cm})$ (Erfah, data belum dipublikasikan).

Kalsium dapat diserap bersama protein dalam bentuk calsium binding protein (CaBP) sebagai asupan substrat untuk pertumbuhan tulang. Semakin baik pertumbuhan tulang, semakin banyak daging dapat melekat karena tulang tempat melekatnya daging, sehingga berdampak pada deposisi protein daging. Menurut Bijanti et al. (2009) Lactobacillus sp. berperan menurunkan kadar keasaman usus, sehingga penyerapan kalsium meningkat. Disamping itu, pada penelitian ini, persentase lemak abdominal perlakuan T4 paling rendah dibanding perlakuan lain (Tabel 2). Rendahnya persentase lemak abdominal memberikan indikasi bahwa pertambahan bobot badan tersebut berdimensi kualitas karena lebih tinggi deposisi protein daripada lemak, baik pada lemak daging maupun lemak abdominal.

\section{KESIMPULAN}

Hasil penelitian dapat disimpulkan bahwa pakan mikropartikel $18 \%$ dikombinasi dengan Lactobacillus sp. $\quad 1,2 \quad \mathrm{ml}$ meningkatkan kecernaan lemak dan pertambahan bobot badan harian, tetapi menurunkan massa lemak daging dan lemak abdominal.

\section{DAFTAR PUSTAKA}

Agustina, L., S. Purwanti dan D. Zainuddin. 2007. Penggunaan probiotik (Lactobacillus sp.) sebagai imbuhan pakan broiler. Seminar Nasional Teknologi Peternakan dan Veteriner. Hal. $552-555$.

Bijanti, R., R. S. Wahjuni dan M. G. A. Yuliani. 2009. Suplementasi probiotik pada pakan ayam komersial terhadap produk metabolik dalam darah ayam. J. Penelit. Med. Eksakta. 8 (3) : 178 184.

Daud, M. 2006. Persentase dan kualitas karkas ayam pedaging yang diberi probiotik dan prebiotik dalam pakan. J. Ilmu Ternak 6 (2) : 126 - 131.

Hartono, E., N. Iriyanti dan R. S. S. Santosa. 2013. Penggunaan pakan fungsional terhadap daya ikat air, susut masak, dan keempukan daging ayam broiler. J. Ilmiah Pet. 1 (1) : 10 - 19.

Kirana, N. G. P. S., I G. N. G. Bidura, dan E. Puspani. 2017. Pengaruh penggunaan ampas tahu terfermentasi khamir Saccharomyces sp. dalam ransum terhadap distribusi lemak dan kolesterol darah broiler. J. Tropical Anim. Sci. 5 (1) : 105 - 119.

Kocher, A., M. Choct, G. Ross, J. Broz dan T. K. Chung. 2003. Effects of enzyme combinations on apparent metabolizable energy of corn-soybean 
meal-based diets in broilers. J. Appl. Poult. Res. $12: 275-283$.

Krismaputri, M. E., N. Suthama, dan Y. B. Pramono. 2016. Pemberian soybean oligosaccharides dari ekstrak bungkil dan kulit kedelai terhadap $\mathrm{pH}$ usus, populasi E. coli, dan $\mathrm{PBBH}$ pada broiler. Mediagro. 12 (2) : 20 -25.

Mentari, A. S., L. D. Mahfudz dan N. Suthama. 2014. Massa protein dan lemak daging pada ayam broiler yang diberi tepung temukunci (Boesenbergia pandu rata Rox B.) dalam pakan. Anim. Agric. J. 3 (2) : 211 - 220.

Mohammed, H. A. dan E. Horniakova. 2012. Effect of using saturated and unsaturated fats in broiler diet on carcass performance. Slovak J. Anim. Sci. 45 (1) : $21-29$.

Salam, S., A. Fatahilah, D. Sunarti dan Isroli. 2013. Berat karkas dan lemak abdominal ayam broiler yang diberi tepung jintan hitam (Nigella sativa) dalam pakan selama musim panas. Sains Pet. 11 (2) : $84-89$.

Sotak, K. M. dan H. H. Stein. 2014. Nutritional value of soybean products. Midwest Swine Nutrition Conference Proceedings, Indianapolis, Indiana, USA

Suthama, N. dan P. J. Wibawa. 2016. Digestibility evaluation of microparticle protein derived from fish meal and soybean meal in broiler chicken. In : Marjuki, A. Ridhowi, W. Andre (Ed.). Proceeding $3^{\text {rd }}$ Animal Production International Seminar $\left(3^{\text {rd }}\right.$ APIS) \& $3^{\text {rd }}$ ASEAN Regional Conference on Animal Production $\left(3^{\text {rd }}\right.$ ARCAP) Seminar Internasional The Sixth International Conference on Sustainable Animal Agriculture for Developing Countries. Malang 19 - 21 October 2016. pp. $214-216$.

Suthama, N. dan P. J. Wibawa. 2017. Feeding microparticle protein composed diet on protease activity and protein utilization in broiler chickens. Seminar Internasional The Sixth International Conference on Sustainable Animal Agriculture for Developing Countries.

Turan, H., Y. Kaya, and I. Erkoyuncu. 2007. Protein and lipid content and fatty acid composition of fish meal produced in Turkey. Turk. J. Vet. Anim. Sci. 31 (2) : $113-117$.

Wahju, J. 1997. Ilmu Nutrisi Unggas. Gadjah Mada University Press, Yogyakarta.

Yunenshi, F. 2011. Pengaruh Pemberian Probiotik Pediococcus pentosaceus Asal Fermentasi Kakao Hibrid terhadap Penurunan Kolesterol Telur Itik Pitalah. Program Pasca Sarjana Universitas Andalas, Padang. (Tesis). 